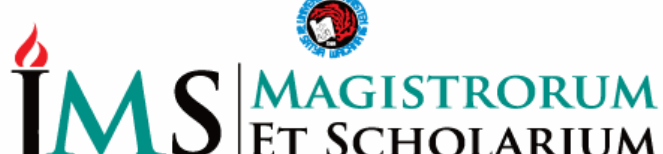 \\ JURNAL PENGABDIAN MASYARAKAT
}

P-ISSN: 2722-9270

\section{Pendampingan Pemetaan Risiko dan Pengendalian Siklus Penerimaan Kas di Gereja Kristen Jawa Ambarawa}

\author{
Ireina Thesa Shaula \\ Lintang Sella Utami \\ Yusak Kharis Windarta* \\ Fakultas Ekonomika dan Bisnis Universitas Kristen Satya Wacana
}

A R T I C L E I N F O

Article history:

Received 01-10-2021

Revised 20-11-2021

Accepted 29-12-2021

Key words:

Gereja, Pengendalian Internal,

Penerimaan Kas,

Pendokumentasian

\section{A B S T R A C T}

The lack of human resources from an accounting background at the Ambarawa Christian Church of Java, therefore the flow data for cash receipts such as DFD, REA, and flowcharts with the aim of making it easier to understand and provide clarity for the congregation and assemblies in terms of cash receipts and management. In addition, even though this organization operates in the non-profit sector, internal control is also needed to overcome and prevent the possibility of fraud in this organization. For this reason, the service team prepares internal control scenarios, both preventive, detective, and corrective.

\section{A B S T R A K}

Minimnya SDM dari latar belakang akuntansi di Gereja Kristen Jawa Ambarawa, maka disusunlah data alur bagi penerimaan kas seperti DFD, REA, dan flowchart dengan tujuan untuk mempermudah dalam pemahaman dan memberikan kejelasan bagi jemaat dan majelis dalam hal penerimaan serta pengelolaan kas. Selain itu, sekalipun organisasi ini bergerak dalam bidang non profit, namun pengendalian internal juga dibutuhkan untuk mengatasi dan mencegah kemungkinan fraud yang ada di dalam organisasi ini. Untuk itu tim pengabdi menyusun skenario pengendalian internal baik preventif, detektif, dan korektif.

\section{PENDAHULUAN}

Gereja merupakan tempat yang biasa digunakan oleh orang-orang beragama Kristen maupun Katolik untuk melakukan ibadah atau biasa disebut sebagai rumah Tuhan (Situmorang, 2014). Gereja merupakan sebuah organisasi yang bergerak dalam bidang nirlaba karena orientasi di dalamnya untuk melayani jemaat. Hal tersebut tidak terlepas juga dari sumber pendapatan gereja yang sebagian besar diperoleh dari sumbangan donatur dan persembahan warga jemaat, sehingga memang tujuan utama

\footnotetext{
*Corresponding author: yusakharis@gmail.com
} 
dari pengelolaan keuangan gereja bukan untuk memperoleh keuntungan finansial. Meski demikian di dalam pengelolaan keuangannya gereja juga perlu dibekali dengan pengendalian yang memadai untuk memitigasi adanya risiko-risiko kecurangan yang berpotensi terjadi dan merugikan, seperti yang terjadi di GKI Serpong, Tangerang Selatan terjadi penyelewengan dana jemaat, pemalsuan data, dan pencucian uang senilai Rp 2,4 Miliar oleh bendahara gereja dan pendeta pada tahun 2015 (Wibowo \& Kristanto, 2017).

Gereja Kristen Jawa (GKJ) Ambarawa merupakan gereja yang terletak di Jalan MGR. Sugijopranoto, No. 1, Kecamatan Ambarawa, Kabupaten Semarang, Jawa Tengah. GKJ Ambarawa merupakan kumpulan gereja di bawah Klasis Salatiga Bagian Utara. GKJ Ambarawa memiliki struktur organisasi yang biasa disebut dengan kemajelisan yang terdiri dari 1 (satu) pendeta, 4 (empat) penatua, dan 9 (sembilan) diaken. Kepemimpinan/kemajelisan dalam GKJ Ambarawa terbagi atas Majelis Pekerja Harian dan Majelis Pemerhati. Majelis Pekerja Harian terdiri atas 2 (dua) ketua majelis, 3 (tiga) sekretaris, dan 3 (tiga) bendahara. Majelis Pemerhati bertugas sebagai penghubung antara komisi dan tim dengan Majelis Pengurus Harian, adapun struktur organisasi GKJ Ambarawa adalah sebagai berikut:

\section{Bagan Majelis Pekerja Harian}

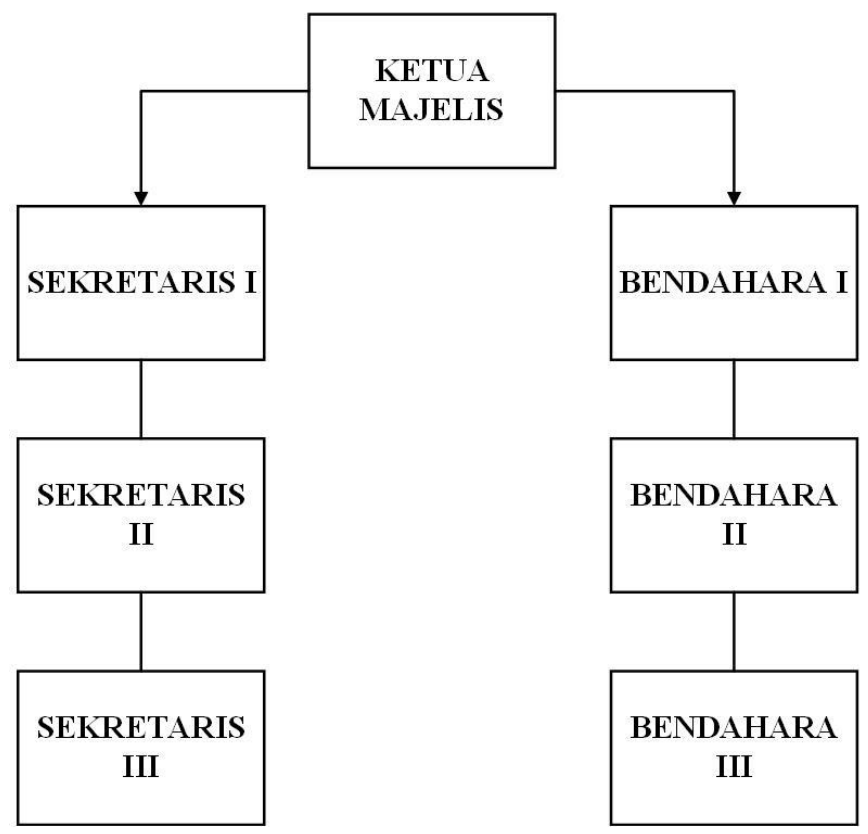

Gambar 1. Bagan Majelis Pekerja Harian

Di GKJ Ambarawa sumbangan sukarela diistilahkan sebagai persembahan dan menjadi salah satu penerimaan kas terbesar. Berdasarkan Pokok-Pokok Ajaran Gereja Kristen Jawa Pasal 20 mengenai Kekayaan Gereja, persembahan dibagi menjadi dua yaitu berupa uang dan barang. Persembahan berupa uang meliputi persembahan mingguan, persembahan bulanan atau persepuluhan, persembahan pembangunan, 
persembahan istimewa, dan jenis persembahan lainnya. Sedangkan, persembahan barang terdiri atas barang tidak bergerak dan barang bergerak.

Pengelolaan penerimaan kas yang baik diperlukan agar kegiatan operasional gereja dapat berjalan secara optimal sesuai dengan tujuan dari gereja. Namun, dengan adanya kondisi pandemi Covid-19, gereja mengalami kondisi yang berbeda, antara lain menurunnya jumlah pendapatan yang bersumber dari persembahan jemaat dan cukup berdampak pada cashflow gereja. Menurut Gunawan Adisaputra, dalam buku Sistem Penyediaan Air Minum, dikatakan bahwa cashflow merupakan pengeluaranpengeluaran dan penerimaan-penerimaan yang timbul akibat adanya kegiatan investasi. Menilik dari fenomena kasus kecurangan yang terjadi di gereja, ditambah dengan kondisi perubahan cashflow akibat pandemi Covid-19 maka diperlukan pengendalian internal gereja yang baik dalam siklus operasional pengelolaan keuangan gereja, salah satunya pada siklus penerimaan kas.

Adanya kelemahan karena kurangnya efisiensi dan efektifitas dari pengendalian internal siklus penerimaan kas, akan mempengaruhi kegiatan operasional serta mengurangi kepercayaan jemaat tentang pengelolaan penerimaan kas yang baik. Menurut Romney \& Steinbart (2016), siklus penerimaan kas merupakan serangkaian kegiatan bisnis dan operasional pemrosesan informasi terkait yang terus menerus menyediakan barang dan jasa kepada pelanggan dan menerima kas sebagai pembayaran atas penjualan tersebut. Menurut IAI dalam PSAK No.45 (2016) organisasi nirlaba merupakan organisasi yang memperoleh sumber daya dari sumbangan para anggota dan para penyumbang lainnya yang tidak mengharapkan imbalan apapun dari organisasi tersebut. Sementara itu diketahui bahwa gereja merupakan organisasi nirlaba yang tidak berorientasi dalam mencari keuntungan.

Gereja sebagai organisasi nirlaba, dalam hal ini GKJ Ambarawa, tidak menjalankan aktivitas bisnis terkait dengan jual beli ataupun kegiatan produksi. Hasil wawancara dan observasi awal dari kegiatan pengabdian masyarakat ini menunjukkan bahwa GKJ Ambarawa telah memiliki pengendalian yang diterapkan guna mengendalikan risiko kecurangan yang ada meskipun belum sepenuhnya optimal dikarenakan masih ada terdapat beberapa risiko yang belum teridentifikasi sehingga berpengaruh pada lemahnya pengendalian yang diterapkan.

Dalam menjalankan aktivitas bisnisnya, mitra pengabdian GKJ Ambarawa melakukan pemrosesan data dan pencatatan kas menggunakan metode manual dan sederhana. Proses pencatatan data dan kas masih dilakukan secara manual dengan mencatat setiap penerimaan kas berupa persembahan ke dalam dokumen fisik yaitu buku kas. Penggunaan sistem atau software Microsoft Excel seringkali hanya digunakan untuk membuat anggaran dan pembuatan laporan keuangan. Selama ini, pengelola keuangan GKJ Ambarawa melakukan penyimpanan uang kas di 2 (dua) tempat yang berbeda yaitu dompet uang kas dan juga di salah satu bank.

Kegiatan pengabdian masyarakat merupakan bagian dari Tri Dharma Perguruan Tinggi. Tujuan dari pengabdian masyarakat ini adalah untuk memberikan pendampingan kepada mitra pengabdian dalam hal ini GKJ Ambarawa dalam melakukan identifikasi risiko terkait siklus penerimaan kas, serta memberikan rekomendasi terkait pengendalian yang bisa ditambahkan dan atau diperbaiki untuk dapat memitigasi keterjadian dan dampak dari risiko tersebut. Berkaitan dengan 
penerapan sistem informasi akuntansi di dalam GKJ Ambarawa tim pengabdi membuatkan sebuah Flowchart, DFD (Data Flow Diagram), dan REA. Harapan lebih lanjut pengabdian masyarakat ini nantinya akan meningkatkan efisiensi dan efektifitas dari pengelolaan keuangan GKJ Ambarawa, khususnya terkait dengan siklus penerimaan kas.

\section{METODE PELAKSANAAN}

Pengabdian masyarakat ini dilakukan pada bulan September hingga Oktober 2020. Adanya Pembatasan Sosial Berskala Besar (PSBB) membuat teknis pelaksanaan pengabdian masyarakat dilaksanakan secara online dengan menggunakan platform Google Meet. Pelaksanaan pengabdian masyarakat di GKJ Ambarawa diawali dengan observasi objek mitra pengabdian kemudian dilanjutkan dengan wawancara bersama bendahara GKJ Ambarawa. Setelah melakukan wawancara, tim pengabdi menelusuri informasi terkait aktivitas penerimaan kas, risiko dan pengendalian yang sudah dilakukan. Risiko diidentifikasi dari setiap aktivitas terkait siklus penerimaan kas di GKJ Ambarawa. Identifikasi risiko ini dilakukan secara menyeluruh baik yang sudah ada maupun yang belum teridentifikasi sebelumnya. Tahapan pelaksanaan pengabdian masyarakat di GKJ Ambarawa tertera pada Tabel 1.

Tabel 1. Jadwal Pengabdian Masyarakat

\begin{tabular}{lll}
\hline \multicolumn{1}{c}{ Pelaksanaan } & \multicolumn{1}{c}{ Aktivitas } & Pelaksana \\
\hline September 2020 & Perkenalan dengan mitra pengabdi & Tim Pengabdi \\
& Pelaksanaan wawancara terkait siklus penerimaan kas & Tim Pengabdi \\
& Diskusi pembuatan bagan alir flowchart siklus & Tim Pengabdi \\
& penerimaan kas dan pendokumentasian DFD dan REA & \\
& Pelaksanaan wawancara mengenai siklus pendapatan & Tim Pengabdi \\
& dan pengeluaran kas guna pembuatan laporan & Tim Pengabdi \\
& pengendalian internal & \\
\hline Oktober 2020 & Pengidentifikasian ancaman dan pengendalian internal & Tim Pengabdi \\
& yang telah diterapkan mitra pengabdi & \\
& Perumusan rekomendasi pengendalian internal atas & Tim Pengabdi \\
& siklus penerimaan kas & \\
& Penyusunan laporan pengabdian masyarakat & Tim Pengabdi \\
\hline
\end{tabular}

Setelah identifikasi risiko dilakukan, maka kemudian dipetakan berdasarkan tingkat keterjadian nya dan dampak jika terjadi, sehingga diperoleh skala risiko yang berada di level tinggi, sedang dan rendah. Berikutnya yang dilakukan adalah identifikasi pengendalian internal yang selama ini telah dilakukan untuk memitigasi risiko-risiko tersebut. Terakhir, perumusan rekomendasi perbaikan dan usulan pengendalian yang dapat dilakukan oleh GKJ Ambarawa. Selain itu sebagai bentuk kontribusi lainnya, tim pengabdi membantu merancangkan dokumentasi sistem informasi akuntansi berupa Flowchart, DFD (Data Flow Diagram), dan REA terkait dengan siklus penerimaan kas, terkhusus yang bersumber dari persembahan. 


\section{HASIL DAN PEMBAHASAN}

Pengabdian yang telah dilakukan ini berjalan sesuai dengan jadwal yang sudah ditetapkan dan selesai tepat waktu. Dari hasil wawancara dengan bendahara GKJ Ambarawa diperoleh informasi bahwa aktivitas penerimaan kas dimulai ketika jemaat mengumpulkan persembahan ke dalam kantong yang diedarkan oleh majelis gereja. Setelah ibadah selesai, tim penghitung persembahan kemudian membawa kantong persembahan untuk dibuka dan dihitung secara manual. Setelah persembahan dihitung secara manual, banyaknya persembahan akan dicatat dalam buku kas pendamping mingguan, dan uang persembahan akan diberikan kepada bendahara gereja untuk dilakukan cek berulang. Setelah jumlahnya sesuai, bendahara akan melakukan pencatatan pada buku kas umum dan juga melaporkan pada admin gereja untuk dipublikasikan dalam Warta Gereja.

Setiap bulannya, bendahara gereja akan membuat laporan keuangan bulanan dengan menggunakan Microsoft Excel. Selanjutnya laporan yang sudah ada diberikan kepada ketua majelis untuk divalidasi dan ditandatangani. Bagian terakhir, laporan akan diarsipkan menjadi dua rangkap print out, rangkap 1 disimpan permanen oleh bendahara dan rangkap 2 disimpan permanen untuk arsip gereja. Setelah tim pengabdi memperoleh pemahaman mengenai proses aliran data dan kas persembahan di dalam siklus penerimaan kas GKJ Ambarawa, kemudian tim bermaksud menggambarkan siklus melalui flowchart. Menurut Romney \& Steinbart (2016) bagan alir atau flowchart, merupakan deskripsi grafis sistem yang dibagi menjadi bagan alir dokumen, sistem, dan program. Pembuatan flowchart siklus penerimaan kas bertujuan untuk menggambarkan prosedur atau proses aliran data dalam sistem yang sudah terbentuk mulai dari persembahan diterima hingga dilaporkan dalam laporan keuangan bulanan gereja. Pembuatan flowchart diperlukan agar pengurus dan jemaat dapat melihat dan memahami dengan mudah mengenai siklus penerimaan kas di gereja. Berikut merupakan bagan alir siklus penerimaan kas GKJ Ambarawa. 


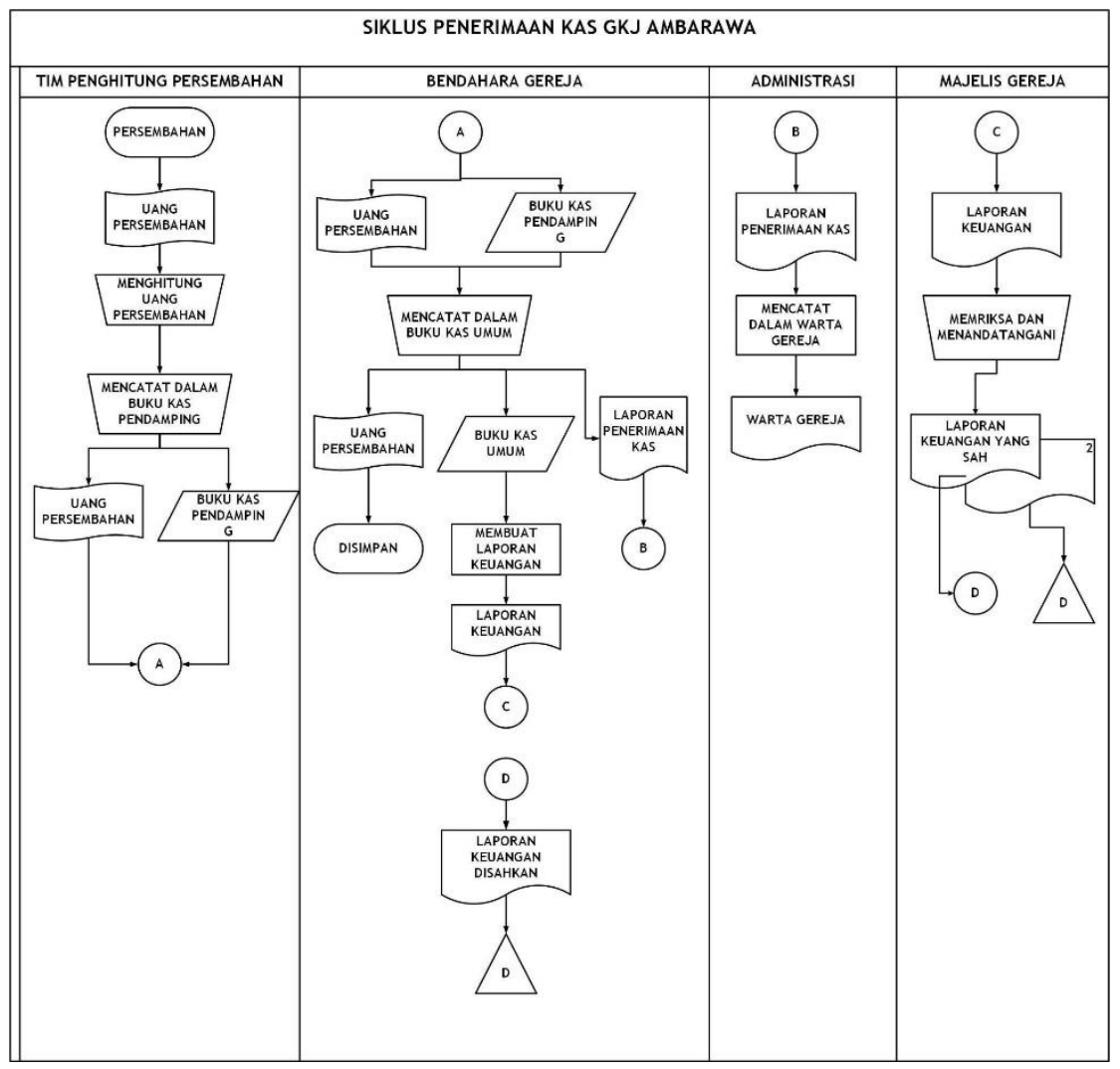

Gambar 1. Flowchart Siklus Penerimaan Kas GKJ Ambarawa

Setelah tim pengabdi membuat flowchart, tim pengabdi kemudian membuat DFD (Data Flow Diagram). Romney \& Steinbart (2016) mengartikan Data Flow Diagram (DFD) sebagai grafis sumber data, arus data, proses perubahan, dan penyimpanan data dan tujuan data. Data Flow Diagram ini untuk mengarahkan bagaimana data yang ada dalam siklus penerimaan kas tersebut diolah. Selain itu, pembuatan DFD juga bertujuan untuk menggambarkan fungsi dan sub fungsi yang mentransformasi aliran data yang berkaitan dengan sistem penerimaan kas GKJ Ambarawa. Tidak hanya menggambarkan DFD dari siklus penerimaan kas, tim pengabdi juga menganalisis serta menggambarkan REA (Resources, Event, and Agents) yang menggambarkan sebuah kerangka kerja akuntansi untuk pemodelan sumber daya, peristiwa, dan pelaku di dalam suatu organisasi yang disertai dengan kardinalitas atau hubungan antara ketiganya. Di dalam REA, data yang berupa akuntansi maupun non-akuntansi dapat diidentifikasi, ditangkap, dan disimpan dalam basis data relasional. Hubungan dari setiap data ditunjukkan melalui kardinalitas yang melekat di setiap bagian berupa one to one, one to many, dan many to many. Berikut merupakan hasil DFD dan REA siklus penerimaan kas GKJ Ambarawa yang sudah dibuat oleh tim pengabdi. 


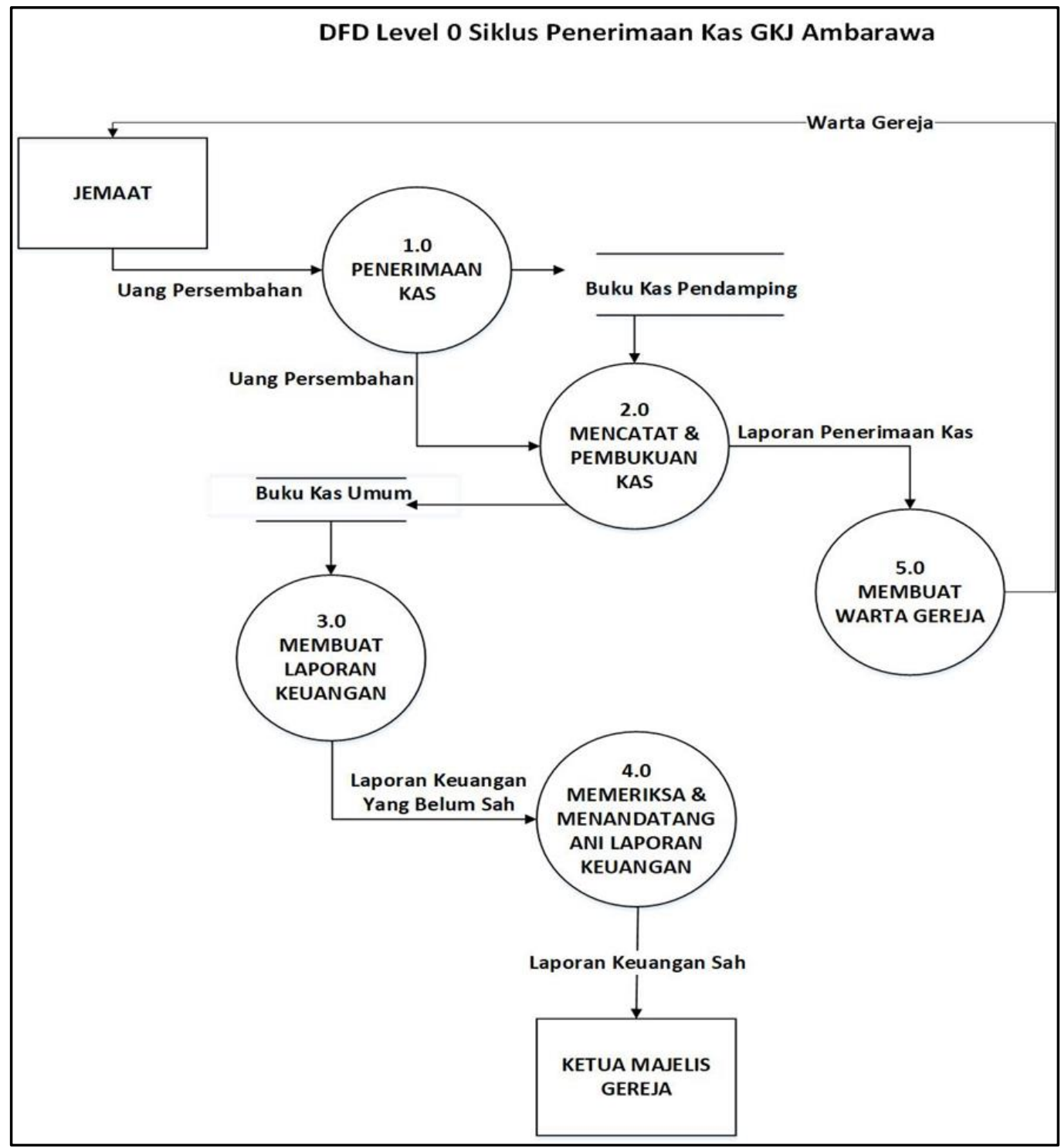

Gambar 2. Data Flow Diagram Siklus Penerimaan Kas GKJ Ambarawa 


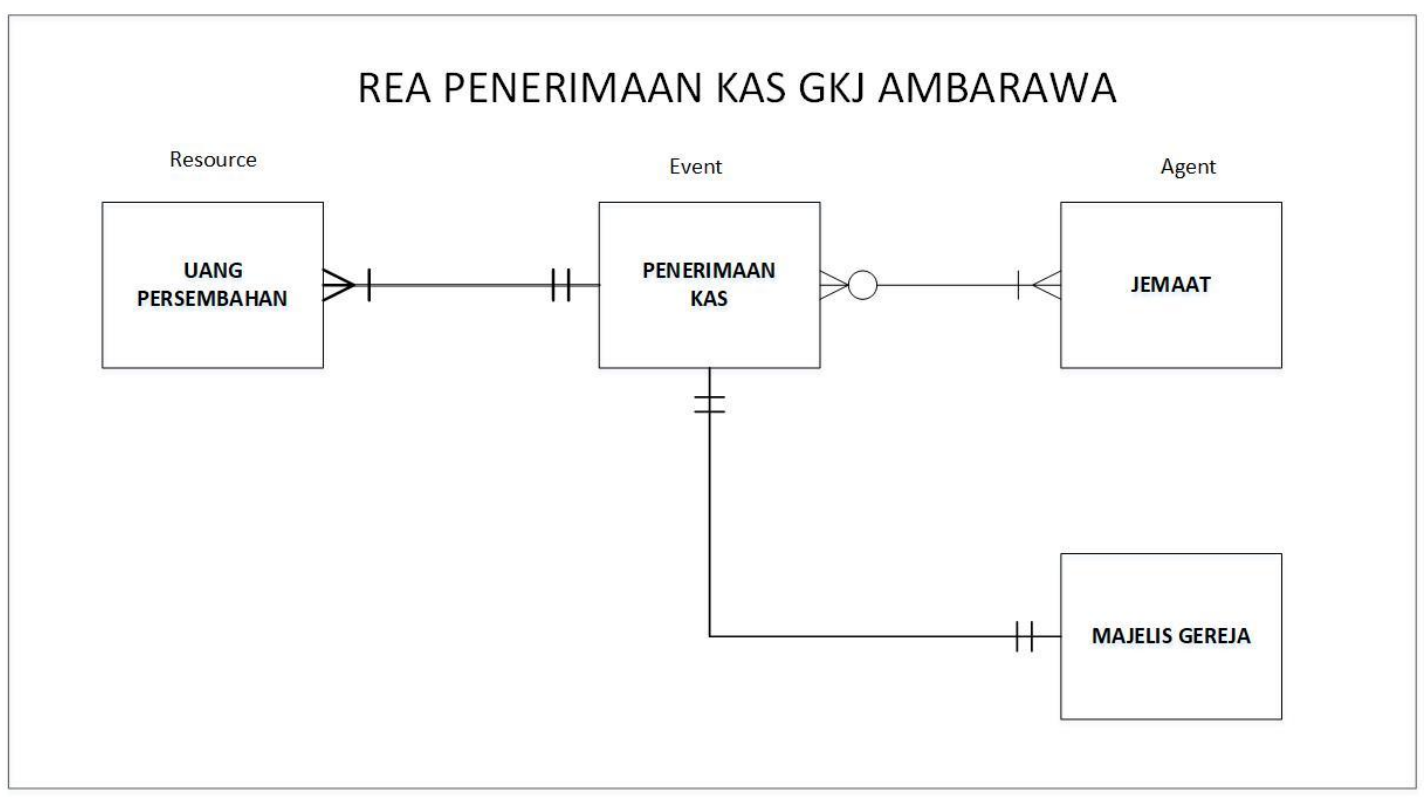

Gambar 3. REA Siklus Penerimaan Kas GKJ Ambarawa

Setelah tim pengabdi memperoleh informasi terkait dengan siklus penerimaan kas, tim pengabdi melanjutkan wawancara terkait pengendalian internal serta melakukan identifikasi mengenai pengendalian internal yang selama ini telah dilakukan untuk memitigasi risiko terkait siklus penerimaan kas di GKJ Ambarawa.

Menurut COSO, terdapat delapan Element Enterprise Risk Management (ERM), salah satunya yaitu penilaian risiko, dalam kegiatan pengabdian yang dimulai dari bulan September hingga Oktober ini juga menghasilkan analisis tersebut. Penilaian risiko (risk assessment) adalah penetapan kemungkinan terjadinya dampak dari sebuah kejadian yang menghambat tercapainya tujuan tertentu (Mardia et al., 2021). Terdapat tiga kondisi yang menyebabkan kecurangan menurut SAS 909, kondisi tersebut seperti insentif/tekanan, kesempatan, dan sikap/rasionalisasi. Ketiga kondisi ini disebut juga sebagai segitiga kecurangan (fraud triangle).

Penetapan analisis risiko dilakukan dalam beberapa tahapan dimulai dari identifikasi ancaman, perkiraan risiko, perkiraan dampak dari risiko, identifikasi pengendalian yang saat ini telah diterapkan, perkiraan biaya dan manfaat, serta menetapkan efektivitas biaya manfaat. Informasi terkait dengan pengendalian internal yang sudah diterapkan dapat menggambarkan tentang kebijakan dan prosedur yang telah diterapkan oleh GKJ Ambarawa untuk memberikan kepastian yang layak bahwa pelaksanaan organisasi di GKJ Ambarawa telah mencapai tujuan gereja dan sasarannya terkait dengan penerimaan kas. Penerapan kebijakan terkait dengan pengendalian internal ini diperlukan oleh pengurus GKJ Ambarawa dalam mengamankan aset gereja baik dalam barang ataupun kas, mengelola catatan dan dokumen yang akurat, guna menyiapkan laporan keuangan yang baik dan sesuai yang ditetapkan, mendorong efisiensi dan efektifitas dalam kegiatan operasional, dan guna memenuhi ketentuan hukum ataupun ketentuan sinode gereja yang berlaku.

Tim pengabdi kemudian mengelompokkan aktivitas bisnis, ancaman, serta 
pengendalian yang telah dilakukan oleh GKJ Ambarawa seperti yang tertera di Tabel 2.

Tabel 2. Pengendalian Internal Siklus Penerimaan Kas

\begin{tabular}{|c|c|c|}
\hline Aktivitas Bisnis & Ancaman setiap aktivitas & Pengendalian yang Telah Dilakukan \\
\hline $\begin{array}{l}\text { Pengumpulan } \\
\text { persembahan }\end{array}$ & $\begin{array}{l}\text { 1. Kesalahan jemaat dalam memasukkan } \\
\text { amplop persembahan karena terdapat } \\
\text { beberapa macam kotak persembahan. } \\
\text { 2. Uang rusak saat pengumpulan } \\
\text { persembahan. }\end{array}$ & 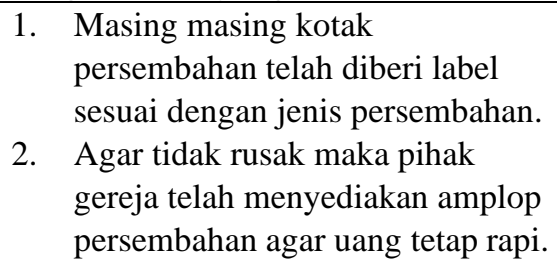 \\
\hline $\begin{array}{l}\text { Penghitungan } \\
\text { uang } \\
\text { persembahan }\end{array}$ & $\begin{array}{l}\text { 1. Terjadi kesalahan hitung persembahan } \\
\text { 2. Pencurian uang persembahan saat } \\
\text { penghitungan } \\
\text { 3. Adanya uang persembahan yang lupa } \\
\text { dihitung } \\
\text { 4. Ketidaksesuaian jumlah uang } \\
\text { persembahan dengan yang dicatatkan } \\
\text { 5. Uang tidak sengaja sobek saat } \\
\text { melakukan pembukaan amplop } \\
\text { persembahan }\end{array}$ & $\begin{array}{l}\text { 1. Pengawasan penghitungan yang } \\
\text { dilakukan oleh majelis lain atau } \\
\text { langsung oleh jemaat } \\
\text { 2. Melakukan hitung ulang agar } \\
\text { kesalahan hitung tidak terjadi } \\
\text { 3. Penghitungan persembahan hanya } \\
\text { dilakukan oleh majelis dan jemaat } \\
\text { yang sudah ditunjuk } \\
\text { 4. Majelis telah dibekali nilai } \\
\text { kekristenan seperti integritas dan } \\
\text { kejujuran } \\
\text { 5. Majelis membuat berita acara bila } \\
\text { ada uang yang sobek atau amplop } \\
\text { yang kosong } \\
\text { Majelis menandatangani laporan } \\
\text { rekapitulasi penghitungan } \\
\text { persembahan sebagai bukti bahwa } \\
\text { nominal uang persembahan } \\
\text { disetujui }\end{array}$ \\
\hline $\begin{array}{l}\text { Penerimaan dan } \\
\text { penyimpanan } \\
\text { uang } \\
\text { persembahan oleh } \\
\text { bendahara dan } \\
\text { bank. }\end{array}$ & $\begin{array}{l}\text { 1. Terdapat risiko uang kas hilang atau } \\
\text { dicuri } \\
\text { 2. Kesalahan jumlah setoran yang akan } \\
\text { disimpan dalam bank } \\
\text { 3. Miskomunikasi penyampaian } \\
\text { informasi penerimaan dan } \\
\text { penyimpanan }\end{array}$ & $\begin{array}{l}\text { 1. Menyimpan uang di tempat yang } \\
\text { aman } \\
\text { 2. Melakukan penghitungan ulang } \\
\text { sebelum setor ke bank } \\
\text { 3. Majelis melakukan pemisahan } \\
\text { tugas antara penerima dengan } \\
\text { penyimpan kas persembahan } \\
\text { 4. Adanya pembatasan akses di } \\
\text { tempat penyimpanan uang kas } \\
\text { tunai } \\
\text { 5. Majelis dan bendahara } \\
\text { menginformasikan saldo } \\
\text { persembahan di setiap minggu } \\
\text { kepada jemaat }\end{array}$ \\
\hline $\begin{array}{l}\text { Pencatatan uang } \\
\text { persembahan } \\
\text { baik secara } \\
\text { manual maupun }\end{array}$ & $\begin{array}{l}\text { 1. Ketidaksesuaian uang persembahan } \\
\text { yang diterima dengan yang dituliskan } \\
\text { dalam laporan rekapitulasi }\end{array}$ & $\begin{array}{l}\text { 1. } \text { Melakukan hitung ulang } \\
\text { pengecekan kembali jumlah uang } \\
\text { persembahan }\end{array}$ \\
\hline
\end{tabular}




\begin{tabular}{|c|c|c|c|c|}
\hline secara komputer. & & $\begin{array}{l}\text { Keterlambatan pencatatan baik dalam } \\
\text { buku kas maupun dalam komputer } \\
\text { File mengenai laporan kas } \\
\text { persembahan hilang dan terhapus }\end{array}$ & $\begin{array}{l}3 . \\
4 . \\
5 .\end{array}$ & $\begin{array}{l}\text { Rekonsiliasi dengan buku kas } \\
\text { pendamping jika laporan } \\
\text { penghitungan tidak sesuai dengan } \\
\text { jumlah uang persembahan } \\
\text { Rekonsiliasi dengan Bendahara } 2 \\
\text { Melakukan konfirmasi dengan } \\
\text { majelis penghitung persembahan } \\
\text { Melakukan agenda verifikasi } \\
\text { (audit) setiap } 4 \text { bulan sekali atau } \\
\text { sesuai kebutuhan } \\
\text { Setiap bulan melakukan rapat } \\
\text { pleno mengenai pelaporan } \\
\text { keuangan } \\
\text { Backup data dalam flashdisk dan } \\
\text { file juga dipegang oleh Bendahara } \\
2\end{array}$ \\
\hline
\end{tabular}

\section{SIMPULAN}

Pengabdian masyarakat yang dilakukan di GKJ Ambarawa telah dilaksanakan dengan baik. Dalam hal ini tim pengabdi membantu memetakan bahwa di dalam rangkaian siklus penerimaan kas GKJ Ambarawa, memiliki kekuatan dan kelemahan. Kekuatan di dalam siklus penerimaan kas ditunjukkan dengan adanya transparansi data keuangan. Hal itu dibuktikan dengan adanya warta gereja, setiap penerimaan kas akan dibuat data penerimaan setiap minggu untuk kemudian dipublikasikan di warta gereja yang nantinya disebarkan kepada jemaat gereja. Adanya pembuatan warta gereja juga sebagai bentuk pengawasan terkait dengan informasi keuangan gereja.

Selain memiliki kekuatan, tim pengabdi menyimpulkan masih terdapat beberapa aktivitas yang berpotensi terjadi kecurangan di dalamnya. Untuk memitigasi hal ini, objek mitra pengabdian sudah menyediakan beberapa alternatif pengendalian permasalahan yang diharapkan mampu meminimalisir adanya tindak kecurangan ataupun aktivitas lain yang menyebabkan penerimaan kas menjadi kurang maksimal. Penerapan pengendalian internal di dalam siklus penerimaan kas yang diterapkan sekedar untuk menjamin bahwa uang persembahan tersebut dapat dikumpulkan dengan baik, tepat waktu, dan jumlahnya sesuai dengan laporan penerimaan. Akan tetapi setelah adanya uraian yang disampaikan oleh bendahara gereja, terdapat beberapa hal yang dirasa masih kurang karena lemahnya pengendalian atau belum tersedianya pengendalian atas permasalahan yang ada.

Tim pengabdi merasa bahwa masih terdapat pengendalian yang dirasa belum mampu memitigasi adanya risiko-risiko kecurangan yang mungkin terjadi yaitu pada pencatatan uang persembahan baik secara manual maupun secara komputer, hal ini disebabkan karena masih terdapat celah seperti merekayasa laporan keuangan untuk memperoleh keuntungan pribadi. Selain itu, pengendalian internal pada aktivitas pengumpulan persembahan juga dirasa kurang maksimal karena amplop persembahan yang memiliki warna sama sering kali membuat jemaat salah memasukkan ke kantong yang seharusnya, sehingga hal ini membuat pendapatan tiap pos persembahan kurang maksimal. 
Merespon dari hal ini, tim pengabdi memberikan beberapa rekomendasi untuk setiap ancaman yang dirasa belum cukup maksimal pengendaliannya meliputi (1) kesalahan jemaat dalam memasukkan amplop persembahan karena terdapat beberapa macam kotak persembahan. Bagian ini juga sering terjadi karena keseragaman warna amplop pada semua jenis persembahan. Untuk itu tim pengabdi memberikan rekomendasi agar pihak GKJ Ambarawa membuat amplop yang berbeda warna dengan tambahan keterangan di setiap bagian depan amplop serta memberi atribut pada kotak persembahan sesuai dengan warna amplop, (2) pembuatan SOP (Standard Operating Procedure) bagi aktivitas pencatatan, tujuan dari adanya SOP ini sebagai pedoman kebijakan yang menjadi dasar dari aktivitas bisnis selain itu diberlakukannya SOP ini berguna untuk meningkatkan akuntabilitas, menciptakan ukuran standar kinerja bagi pengurus organisasi, serta menunjukkan bahwa kinerja organisasi efisien. SOP yang baik juga harus dievaluasi setidaknya dalam jangka waktu setahun sekali agar SOP masih relevan.

\section{DAFTAR PUSTAKA}

Ermawati,R. (2018). Sistem Penyediaan Air Minum.Unimma Press. https://www.google.co.id/books/edition/Sistem_Penyediaan_Air_Minum_Studi_ Kasus/VwKGDwAAQBAJ?hl=en\&gbpv=0

IAI. (2016). Pernyataan Standar Akuntansi Keuangan No. 45. In Ikatan Akuntan Indonesia.

Mardia, Tanjung, R., Karim, A., Ismail, M., Wagiu, E. B., Sudarmanto, E., Supitriyani, Sihotang, J. I., Martina, S., Damanik, E. O. P., Purba, B., \& Ardiana, D. P. Y. (2021). Sistem Informasi Akuntansi dan Bisnis (R. Watrianthos \& J. Simarmata (eds.)). Yayasan Kita Menulis.

Mekari. (2021). Fraud Triangle: Mencari Penyebab Kecurangan dalam Keuangan Bisnis. Jakarta Pusat, DKI Jakarta, Indonesia.

Romney, M. B., \& Steinbart, P. J. (2016). Sistem Informasi Akuntansi (Accounting Information System) (14 (ed.)). Pearson.

Romney, M. B., \& Steinbart, P. J. (2020). Accounting Information Systems, Enhanced eBook, Global Edition (15th Edition). Pearson International Content. https://bookshelf.vitalsource.com/books/9781292353371

Sinode GKJ, Pokok-Pokok Ajaran Gereja Kristen Jawa, Semarang. 2005.

Situmorang, J. T. H. (2014). Sejarah Gereja Umum. Penerbit Andi.

Wijayanto, Nugroho. (2001). Sistem Informasi Akuntansi. Jakarta: Penerbit Erlangga.

Wibowo, E. A., \& Kristanto, H. (2017). Korupsi dalam Pelayanan Gereja : Analisis Potensi Penyimpangan dan Pengendalian Internal. Jurnal Integritas, 3(2), 105136. 